ISSN 2078-6441. Вісник Львівського університету. Серія географічна. 2013. Випуск 42. С. 112-120. Visnyk of the Lviv University. Series Geography. 2013. Issue 42. P. 112-120.

911.3:32

\author{
: \\ иросл в ністрянський \\ ьвівський н ціон льний університет імені в н \\ вул. . орошенк , 41, 79000, м. ввів, кр їн
}

икон но порівняльний н ліз цілей т основних н прямів геополітики получених $\mathrm{T}$ тів мерики, еликої рит нії, імеччини, р нції, осії т ит ю. зн чено місце кр їни в геополітиці великих держ в. озкрито суперечності ре ліз ції великими держ в ми своїх геополітичних інтересів у контексті світової безпеки т зб л нсов ного розвитку.

лючові слов : геополітик, геополітичний н ліз, великі держ ви, зовнішня політик , геополітичні інтереси.

дром пр ктичної геополітики є зовнішня геополітик держ в і міждерж вних об'єдн нь, які, спир ючись н ефективне використ ння елементів геопростору, пр гнуть зміцнити свої позиції н міжн родній рені, з безпечити економічні, культурні, інформ ційні т інші інтереси. дійснення зовнішньої геополітики, як слугує інструментом з безпечення життєво в жливих потреб, є необхідною передумовою життєдіяльності кожної держ ви, хоч с мі зовнішньогеополітичні кроки можуть і не м ти концепту льного чи ідеологічного обгрунтув ння, бути природною ре кцією н ре льні зовнішньогеогр фічні обст вини. огляду н обсяг потреб, ре льних викликів т можливостей геополітичні мбіції н йбільше вл стиві с ме великим держ в м.

ст нніми рок ми в укр їнській н уковій т публіцистичній літер турі з'явилося 6 г то публік цій щодо геополітичної проблем тики. дн к більшість з них - це лише викл д відомих історичних геополітичних доктрин. кож дост тньо добре висвітлено геополітичну зумовленість зовнішньої політики окремих держ в, проте зовсім м ло публік цій, присвячених порівняльному н лізу їхньої геополітики в контексті укр їнських інтересів. суспільно-геогр фічній літер турі лише окремі спекти цієї проблем тики висвітлено в пр цях . р йчевського, . т фійчук , . ценк [3], . рохимчук, . едунь [5]. б’єктивний н ліз геополітичних проблем кр їни в контексті вз ємин 3 іншими держ в ми, н с мперед осією, можн відшук ти й у політичній публіцистиці, зокрем, у публік ціях . p бовського, . осєв , . едведєв , . лія, . ом нчук т ін. одноч с деякі пр ці геополітичного х p ктеру, підготовлені геогр ф ми т негеогр ф ми, вирізняються некритичним з своєнням різних підходів геополітики сили, сприйняттям їх як без льтерн тивних моделей у міждерж вних вз ємин х (ф т лізм міфічного протистояння цивіліз цій суходолу і моря, неминучість зіткнення цивіліз цій т ін.) [2]. омітне подекуди й мех нічне відтворення російських євр зійських геополітичних стереотипів і розгляд через їхню призму зовнішньої геополітики великих держ в т їхніх вз ємин з кр їною.

тже, з огляду н недост тність пр ць синтетичного х р ктеру, які д в ли 6 змогу всебічно розкрити х р ктерні риси т суперечливі моменти геополітики великих

(C) ністрянський ., 2013 
держ в, н ш мет - усебічне й цілісне відобр ження всіх скл дових зовнішньогеополітичної діяльності получених т тів мерики, еликої рит нії, імеччини, $\mathrm{p}$ нції, осії т ит ю в контексті перспектив ре ліз ції укр їнських геополітичних інтересів. жерельну основу т кого н лізу ст новлять офіційні доктрини великих держ в (зовнішньополітичні, військові), сукупність пок зників диплом тичної і зовнішньоекономічної ктивності т експертні оцінки. методології порівняльного н лізу геополітики великих держ в в жливо зіст вити пр ктичні зовнішньогеополітичні дії н їхню відповідність з г льним тенденціям розвитку політичного світоустрою, інтерес м безпеки т зб л нсов ного соці льно-економічного розвитку.

йбільше н формув ння конфігур ції пр ктичної геополітики вплив ють получені $m$ ти мерики, м ючи всі потрібні в желі силового тиску (і військові (н йпотужніші мобільні військ швидкого ре гув ння), і ст тусні (постійний член ди езпеки , член ядерного клубу), орг ніз ційні (широке коло союзників), т кож економічні т культурно-інформ ційні). езв ж ючи н деякі відмінні кценти в геополітиці різних президентських дміністр цій, основне геополітичне з вдння

3 кіния ст. $з$ лиш лося ст більним - підтрим ння глоб льного верховенств , всесвітне поширення лібер льної демокр тії. територі льно-політичному вимірі основні зусилля мерик нської геополітики були спрямов ні н з безпечення контролю 3 ситу цією в т ких кр їн х т регіон х світу: 1) інші мерик нські держ ви; 2) вропейський оюз т ентр льно- хідн вроп ; 3) івденно- хідн зія, н с мперед лизький хід, т зійсько- ихооке нський регіон.

рив лий ч с, ж до поч тку ст., обмежув ли свої геополітичні мбіції с ме мерик нськими континент ми, проголошуючи політику невтруч ння у європейські спр ви. ьогодні збереження виріш льного впливу в мериці $є$ одним з пріоритетів мерик нської геополітики з огляду н союзницькі відносини 3 н дою т деякими іншими держ в ми, економічні зв'язки в контексті функціонув ння об'єдн ння , природно-ресурсні інтереси, проблеми нелег льної мігр ції т контр б нди н ркотиків тощо. е н йбільше стосується сусідніх держ в т центр льно мерик нського регіону. дн к івденн мерик в геостр тегічних пл н $х$ порівняно з іншими регіон ми, через різні обст вини, н с мперед н рост ння викликів мерик нським інтерес м в інших регіон х світу, уже не $е н$ перших місиях. омітне н віть деяке посл блення позицій получених т тів, озн к ми чого є: ) зменшення кількості відверто орієнтов них н керівних еліт і появ політичних режимів 3 нтив шингтонською риторикою; б) відновлення відносин більшості л тино мерик нських держ в $з$ убою - основним геополітичним противником у цій ч стині світу; в) поступове поширення геополітичної ідеології “ тинськ мерик - для л тино мерик нців”, що є своєрідною “інтерпрет цією-відповіддю” доктрині онро. європейських спр в х геополітик проходил в н прямі розширення і зміцнення , збереження союзницьких вз ємин з європейськими лідер ми. ме в розширенні н схід мерик нськ геополітичн діяльність виявил ся н йрезульт тивнішою. ередовище нових членів виявляе і н йбільшу лояльність щодо мерик нських геостр тегічних пл нів. одноч с позиції т ких “ст рих" європейських лідерів, як імеччин т р нція, не з вжди узгоджув лися з погляд ми , хоч зг лом через структури , інші чинники полученим т т м т к чи ін кше вд в лося виробити консолідов ну позицію.

уперечливий х р ктер м л і м є геополітик стосовно постр дянських т постюгосл вських кр їн. постюгосл вському просторі конструктивними були кроки 
т хідної вропи щодо створення сприятливих передумов для міжн родного визн ння т ких колишніх республік , як ловенія, орв тія, кедонія, пізніше орногорія. одноч с у жорстких воєнних діях проти ербії (1999), незв ж ючи н провок ції з боку сербського комуністичного керівництв, т кож у просув нні нез лежності осово, політичній тр нсформ ції оснії т ерцеговини виявил ся певн упередженість, не декв тність експертних оцінок, н дмірне з стосув ння сили, що призвело до певного відступу від чинних принципів міжн родного пр в . оч все ж с ме $з$ вдяки т $\quad$ вд лося досягти мирного врегулюв ння низки конфліктів у цьому регіоні т уникнути ще більших жертв.

продовж усього постр дянського періоду помітною бул і відсутність чітких принципів геополітики щодо осії, вн слідок чого получені т ти т к і не змогли суттєво посприяти формув нню в цій геостр тегічно в жливій для всього світу держ ві передб чув ного демокр тичного режиму. ізні прикл ди геополітичного нехтув ння осією як великою держ вою н поч тку 90-х років ст. н тлі вл сних гегемоністських мбіцій призвели до м сового поширення в геополітичній свідомості росіян рев ншистських н строїв, відт к і появи вторит рного політичного режиму. под льше безпринципне з гр в ння з режимом . утін д ло йому к рт-бл нш н здійснення гегемоністської геополітики н усьому постр дянському просторі, $з$ винятком держ в лтії. обто т їхні союзники ф ктично визн ли постр дянський світ як територію особливих інтересів осії.

уперечливий х р ктер м л і м є геополітик щодо кр їни, хоч сум рний конструктивний вплив усе ж перев ж є. окрем , упродовж усього періоду нез лежного розвитку кр їни були г р нтом їі держ вного суверенітету т цілісності.

в мерик нських геополітичних моделях, популярних серед політичної еліти, відводили помітне місце кр їні в процес х геополітичної тр нсформ ції хідної вропи, хоч здебільшого не як с мостійному суб'єктові, лише як геополітично зн чущій кр їні. дн к деякі спроби безпосереднього впливу н політичну ситу цію в кр їні н вряд чи д в ли укр їнському суспільству позитивні результ ти. ріоритетною підтримкою з боку користув лися не укр їнські н ціон льно-демокр тичні сили, лібер льно-космополітичні, з проросійськими геокультурними орієнт ціями, що нівелюв ло ідею цілісної н ціон льної держ ви, не сприяючи формув нню і 3 г льнон ціон льної ідентичності. едост тньою є кож підтримк з боку поступ льного економічного розвитку кр їни. прикл д, з обсягом інвестицій в економіку кр їни 2007 р. були лише н сьомому місці, поступ ючись 3 цим пок зником, зокрем , т ким м лим держ в м вропи, як ідерл нди й встрія. е зовсім сприятливими є умови для укр їнського експорту н ринку : його обсяги в 2007 р. ст новили лише 2,1\% від усього укр їнського експорту, що утричі менше порівняно 3 уреччиною і н віть менше порівняно з ілоруссю, 3 хст ном і горщиною [4, с. 272]. йбільших пров лів з зн л геополітик н лизькому ході, де полученим т т м т к і не вд лося усунути п лестино-ізр їльський конфлікт, оптимізув ти в3 ємини зр їлю із сусідніми держ в ми. безпечення процесу творення держ ви зр їль, обстоюв ння полученими т т ми її інтересів м ло й м є 3 г лом конструктивний $\mathrm{x}$ р ктер, одн к м ло поєднув тись із декв тним розумінням інтересів

лестини т сусідніх $\mathrm{p}$ бських держ в. одноч с 3 йняти неупереджену об'єктивну позицію полученим т т м вд в лося зрідк . о позитивів треб з числити хіб що врегулюв ння ізр їльсько-єгипетських відносин. 
н чним пров лом зовнішньої геополітики получених т тів ст ли воєнні к мп нії проти р ку т фг ніст ну, зумовивши ще більшу дест біліз цію в цьому регіоні, глоб лізув вши іï нег тивні н слідки т ускл днивши перспективи врегулюв ння. е льною виявил сь небезпек поширення політичної нест більності в сусідні кр їни й регіони, зокрем , кист н і ентр льну зію. еополітик сили, яку проводили в івденно- хідній зії, призвел до мобіліз ції різних кр йніх фунд мент лістських формув нь. ідбул ся р дик ліз ція зовнішньої політики р ну, з грожуючи новим воєнним конфліктом із

геополітичній орг ніз ції суч сного світу особливе місце з б г тьм п р метр ми посід $є$ зійсько- ихооке нський регіон. я величезн територія i кв торія стр тегічно в жлив для зовнішньої геополітики , які вл сне є його скл довою, н с мперед, у контексті безпеки, дже зійсько- ихооке нський регіон був одним з центр льних полігонів воєнних дій у ругій світовій війні, де получені т ти з зн ли стр шних уд рів ( ірл- рбор) і здобули в жливі перемоги. р ховуючи уроки минулого, с ме у цьому регіоні зосереджують свої основні військові б зи т потужні збройні сили. ід ч су ругої світової війни в зійсько- ихооке нському регіоні з лишил ся низк невирішених проблем (об'єдн ння ореї, ит ю). собливо скл дною $є$ суч сн дин мік геоекономічних і геокультурних тенденцій т конкуренція з лідерство в різних сфер х. ля контролю н д ситу цією в цьому регіоні получені т ти мерики сформув ли систему союзницьких відносин (з понією, івденною ореєю, встр лією, овою ел ндією т деякими іншими кр їн ми). йбільші зусилля мерик нської геополітики спрямов ні н умиротворення північнокорейського тот літ рного режиму, безпеку йв ню, здобуття позитивних результ тів у конкуренції з лідерство з осією і ит єм, в геоекономічному спекті-із понією. езв ж ючи н те, шо зусилля шодо обмеження геополітичного впливу ит ю т нейтр ліз ції небезпек з боку режиму здебільшого були м лоефективними, полученим т т м усе ж вд ється поки що зберіг ти в зійсько- ихооке нському регіоні контрольні й домінуючі позиції.

жливим інструментом ре ліз ції зовнішньогеополітичних інтересів

$\epsilon$. явність широкого кол впливових союзників т військової орг ніз ції зг лом є однією з основних підв лин мерик нської н ддерж вної могутності. все ж однозн чно ототожнюв ти зовнішньо геополітичні позиції $\quad$ т

бг тьм озн к ми - ие своєрідний синтез геополітичних інтересів $і$ геополітичної стр тегії $m$ вропейського оюзу. якщо серед провідних європейських членів елик рит нія н м г ється йти строго у ф рв тері геополітики, , ре лізуючи спільні геополітичні інтереси в вропі т в держ в х півдружності (зон рит нського впливу), то імеччин i $\mathrm{p}$ нція 3 б г тьм пит ннями виявляють особливі позиції. опри те, що імеччин, з огляду н всі обст вини, пов'яз ні 3 ругою світовою війною, не н м г ється ктивно вплив ти н геополітичну ситу цію поз меж ми вропи, у геополітично зн чущих європейських спр в х (щодо розширення , , вз ємин х 3 осією т ін.) її позиція суттєво позн ч ється н виробленні з г льної геополітичної лінії хідної вропи.

орівняно 3 імеччиною сфер геополітичних інтересів $p$ нцї є зн чно ширшою, i, відповідно, геополітичні впливи охоплюють більше коло міжн родних регіонів, особливо тих, де поширен фр нцузьк мов . е з ч сів президент . де олля, який інтуїтивно хотів зберегти з р нцією ст тус с мостійного геополітичного лідер , ця держ в , з лиш ючись союзником , пр гне демонструв ти с мостійність геополі- 
тичних рішень. р нція, м ючи зн чний військовий потенці л, у тому числі й ядерний, зберіг є міцні геополітичні позиції н с мперед в фриці, менше - у б сейні рибського моря т ке нії, вплив ючи певною мірою і н внутрішньополітичну ситу цію в н ді т зовнішню політику цієї держ ви через н явність зн чної кількості фр нкомовного н селення. ме з вдяки безпосередньому політичному втруч нню

р нції впродовж двох ост нніх десятиліть відновлено відносний пр вопорядок і ст більність у низці держ в фрики. вирішенні близькосхідних проблем р нція н м г л ся порівняно більше, ніж , вр ховув ти інтереси р бських кр їн.

вз ємин х з кр їною геополітик імеччини т р нції є недост тньо конструктивною. імецькі й фр нцузькі з соби м сової інформ ції т політичні кол ч сто розгляд ють укр їнську проблем тику в російській інтерпрет ції. е зумовлено різними чинник ми, зокрем, поширеністю в деяких інтелекту льних середовищ х імеччини т р нції тр диційних москвофільських н строїв, зрост нням енергетичної з лежності від осії. крім того, геополітичне “з гр в ння” цих держ в 3 осією, яке іноді передб ч є і зд чу укр їнських інтересів, є демонстр цією с мостійних геополітичних мбіцій у їхніх вз ємин х із . проектув нні з г льноєвропейських процесів імеччин т р нція “ляк ються" т кож зн чних розмірів кр їни.

ег тивні моменти геоекономічної політики р нції т імеччини спричинили зрост ння з лежності окремих держ в вропейського оюзу від пост ч нь російського г зу вн слідок незд тності з безпечити диверсифік цію г зових потоків, що виявилося, зокрем , у г льмув нні проекту NABUCCO, у якому було з пл нов но тр нспортув ння до ентр льної вропи к спійського г зу через уреччину, т підтримці російських м гістр льних г зопроводів в обхід кр їни і ілорусі - “ івнічного потоку” т

“ івденного потоку”.

ругою після держ вою, як вплив є н 3 г льну конфігур цію світової зовнішньої геополітики, є осія. е пов'яз но і з їі розмір ми, і $з$ геогр фічним положенням, одн к н йбільше - 3 історичними передумов ми, дже ця держ в , як метрополія , ще порівняно нед вно м л н ддерж вний ст тус, суч сн осія пр гне зберегти хоч би ч стину попередніх впливів. ісля розп ду осія теоретично м л ш нс ст ти сильною й вторитетною н ціон льно-демокр тичною держ вою, впливовість якої визн ч ли б не лише військов могутність т енергетичні ресурси, й вторитетн політик у внутрішніх спр в х т конструктивн співпр ця з сусідніми держ в ми н 3 с д х розуміння їхніх суверенних пр в т інтересів. дн к впливовість н ціон льно-демокр тичних сил у осії бул (i $є$ сьогодні) мінім льною. ідповідно, не було сформов но геополітичної моделі осії як н ціон льнодемокр тичної держ ви, впливового лідер міжрегіон льного чи н віть глоб льного зн чення, в зм г нні російських лібер льно-космополітичних т імперських політичних сил н тлі тот льного розкр д ння держ вного м йн $\mathrm{T}$ зубожіння н селення перемогли імпері лісти. ому з 2000 p. осія взял твердий імперський курс н “збир ння земель” колишнього у різних форм х (створення союзних держ в, інтегр ційних економічних проектів, військових блоків), вим г ючи міжн родної ідентифік ції постр дянського простору як зони виняткових російських інтересів. кий iї вибір несе різні з грози не лише новим постр дянських держ в м, й с мій осії, як все ж не м є дост тньо ресурсу для імперської політики, тому може з зн ти кр ху н с мперед ун слідок внутрішнього н длому.

огляду н імперські стр тегічні уст новки, основні зовнішньогеополітичні пр гнення осії т кі: 1) якомог більше притягнути до свого держ вного орг нізму 3 
допомогою економічних, культурно-інформ ційних т безпосередньо політичних чинників держ ви колишнього , створюючи в перспективі передумови і щодо можливого відновлення в м йбутньому російської імперії; 2) посилити вплив н

держ ви-лідери ( імеччину, р нцію, т лію), відтягуючи їх усім з соб ми від

; 3) створюв ти н всіх рівнях передумови для підтягув ння вз ємин із до рівня п ритетних, виявляючи пр гнення знову ст ти полюсом сили глоб льного зн чення; 4) домогтися вигідних економічних відносин з ит єм, 3 сприятливих обст вин н в'яз ти цій держ ві проекти енергетичної з лежності від осії.

скільки протяжність держ вної території т держ вного кордону є великими, то поле геостр тегічних інтересів осії охоплює різні сектори ( зійсько-тихооке нський, центр льно зійський, к вк зький, укр їнсько-молд вський, білоруський, б лтійський, фінсько-ск ндин вський, рктичний, європейський, мерик нський), н кожному 3 яких - свої пріоритети. окрем , н лекому ході і в ибіру для осії в жливо припинити н ступ ит ю (демогр фічний, економічний) і з безпечити н рощув ння експорту в цю кр їну вл сних енергоносіїв. нший кту льний спект російської геополітики в цьому секторі - це протидія пр гненням понії повернути собі чотири острови урильського п см , відторгнені дянським оюзом у ході ругої світової війни. ентр льній зії для осії в жливо зміцнити економічні позиції, військову т культурно-інформ ційну присутність, не допуск ючи проникнення в регіон ісл мського фунд мент лізму. н чні зусилля осія докл д $\epsilon$ для того, щоб позб вити центр льно зійські держ ви с мостійності в пост ч нні енергоносіїв у інші держ ви, н с мперед у вропу, викуповуючи їхні г зові ресурси.

дним із н йскл дніших секторів російської зовнішньої геополітики є івденний

вк з, де осія пр гне сформув ти стр тегічні пл цд рми ( бх зія, івденн сетія), союзні відносини ( ірменія), усіляко не допуск ючи розширення впливу

слідком т кої російської геополітики в цьому секторі ст в російсько-грузинський воєнний конфлікт, який підтвердив зрост ння гресивної н ступ льності в іiї геополітичних діях.

російських геополітичних моделях перев ж є б чення кр їни як втономної скл дової російської імперії, тому пріоритетним з вд нням російської геополітики у вз ємин х з кр їною є недопущення економічного і політичного просув ння н хід ун слідок широкої мобіліз ції всіх прор дянських т проросійських сил, і, відповідно, створення з лежного політичного режиму, готового до інтегр ції в осію н з с д $\mathrm{x}$ поєдн ння різних ідеологічних пл тформ (р дянсько-комуністичної, євр зійської, слов'янської). нший в жливий н прям - це з безпечення домінув ння російської культури в кр їні, под льше формув ння культурно-російської ідентичності [1, с. 4-7].

сновн мет геополітики осії щодо олдови поляг є в недопушенні її под льшої інтегр ції з умунією, створенні умов для поглиблення економічної з лежності від осії. цій геополітиці як основні в желі використовують с мопроголошену ридністровську республіку, де осія зберіг є свої військові ч стини, т впливову комуністичну п ртію.

пл н х відновлення нової російської великодерж ви першим ет пом м ло ст ти поглин ння ілорусі вн слідок розширення функцій т к зв ної союзної держ ви, створеної ще 1997 р. дн к через різні обст вини, зокрем , через суперечливу політичну поведінку білоруського керівництв у вз ємин х з російськими лідер ми, деякі позитивні моменти нез лежного соці льно-економічного розвитку с мої ілорусі, цього не ст лося. 
нші геополітичні з вд ння ст вить осія у лтійському регіоні. скільки держ ви лтії ( стонія, твія, итв ) уже є і член ми , і член ми, то сподів ння н їхне держ вно-політичне "повернення" до будь-яких російських імперських проектів цілком нере льні. кту льною для осії тут є лише підтримк етнічних росіян (російським політик м вигідніш конструкція “російськомовне н селення") як пл цд рму збереження своїх геополітичних інтересів. огляду н відокремлене геогр фічне положення т історично-політичні передумови для осії в жливе недопущення нег тивних тенденцій соці льно-політичного розвитку свого б лтійського нкл ву лінінгр дської обл сті.

опри досить сприятливі економічні відносини, у геополітичних вз ємин х осії 3 інляндією т к чи ін кше виник ють окремі тертя, зокрем, пов'яз ні з історією боротьби інляндії з нез лежність від осійської імперії, нерівнопр вними відносин ми під ч с вст новлення кордону, ст новищем у осії к релів - спорідненого 3 фін ми н роду. одноч с основу геополітичної скл дової політики осії щодо орвегії ст новить пит ння природокористув ння т рктики з г лом, які особливо кту лізув лися з огляду н зміни клім ту. рктичний вектор російської геополітики охоплює всілякі н м Г ння з лучити провідні н фтог зодобувні комп нії світу до співпр ці, т кож зміцнення системи військової безпеки у цій велетенській рктичній смузі.

г торівневий т б г товекторний х р ктер м є геополітик осії щодо $\mathrm{T}$

, у контексті якої використовують різні з соби т ргументи. вз ємин х з об’єдн ною вропою н йрезульт тивнішим в желем впливу осії ст ло зрост ння обсягів пост ч ння г зу з помітним пр гненням з воюв ти в цій сфері монопольні позиції і зробити ентр льну, хідну і івденну вропу енергетично з лежною від осії. одноч с у вз ємин х із основним ргументом 3 лиш ється російський військовий потенці л - другий 3 зн ченням у світі. своїх мбіціях поступово н близитися до мерик нської геополітичної зн чущості осія н м г ється зн йти зі полученими т т ми і спільні регіон льно-політичні інтереси, сприяючи, зокрем , протидії ісл мському фунд мент лізму в ентр льній зії, підтримуючи риторику боротьби проти міжн родного тероризму.

гляд лише з г льних контурів зовнішньої геополітики осії свідчить про те, що російськ держ в н дто б г то суспільної енергії витр ч є н підтвердження своїх великодерж вницьких мбіцій, що оберт ється величезними втр т ми для російського суспільств , зумовлюючи, зокрем , ще більші диспропорції в соці льному розвитку т економічній освоєності території осії. мперськ геополітик, передб ч ючи симіляцію великих груп н селення, з грожує і с мому російському н родові поступовою втр тою с мобутності. е ліз ція цієї політики потребує постійного н гніт ння злоби, гресивності, пошуку зовнішніх і внутрішніх ворогів, що сильно виявилося в російському соціумі ост нніми рок ми, з кл д ючи у ньому передумови под льших соці льних вибухів. еєні дії в рузії 2008 р. з свідчили і можливість відч йдушної в нтюрності в російській геополітиці щодо сусідніх держ в, коли осія розр ховув л н відсутність одност йності і рішучості щодо декв тної ре кції з боку міжн родного співтов риств . о цього осію підштовхують і внутрішні чинники, н с мперед пр гнення припинити з вжди кту льні для цієї держ ви дезінтегр ційні процеси.

обре продум ний системний х р ктер м є зовнішня геополітик um ю, як своєрідно поєднує н ступ льність і жорсткість 3 певною обережністю й гнучкістю.

iii основі - по-перше, усебічний 3 хист економічних інтересів, створення всіх передумов для зб л нсов ного економічного розвитку, по-друге, з вершення 
об'єдн ння кр їни. спішність ре ліз ції першого стр тегічного з вд ння підтверджують високі темпи кит йської економіки, н віть з ур хув нням нег тивних зовнішньоекономічних тенденцій. $є$ зн чні здобутки і в об'єдн вчій геополітиці інтегр ція янг ну ( онконгу) 1997 р. т оминю ( к о) 1999 р. н $з$ с д х моделі “одн держ в - дві системи”, як з свідчил вміння т готовність ит ю зн ходити гнучкі геополітичні рішення. одібні підходи 3 стосовує і щодо йв ню, проте успішність їхньої ре ліз ції з леж тиме від внутрішньополітичних тенденцій розвитку с мого остров . орсткий х р ктер геополітики ит ю виявляється в різкій протидії спроб м створити внутрішню політичну опозицію в держ ві, т кож у протидії н м Г нням політично розхит ти ситу цію в ибеті, інших н ціон льних $\mathrm{p}$ йон х. н слідок т кої позиції всі н м г ння орг ніз ції з поч тку ст. мережевого геополітичного тиску н ит й виявилися безрезульт тними.

лекоглядною $є$ геополітик ит ю і стосовно колишніх сусідніх постр дянських т посткомуністичних держ в, зокрем осії, як сьогодні виявляється здебільшого в н рощув нні економічної т демогр фічної присутності, проте 3 огляду н деякі історично-політичні передумови (дуже в жливі для кит йської мент льності), передусім щодо історичної н лежності ит ю деяких регіонів, не може не передб ч ти й інші стр тегічні цілі. ур хув нням усіх об'єктивних тенденцій зовнішня геополітик ит ю уже н н йближчу перспективу визн ч тиме х р ктер пр ктичної вз ємодії основних міжн родних суб'єктів н зійському субконтиненті т в зійськоихооке нському регіоні, тр нсформуючи і з г льну просторову конфігур цію пр ктичної геополітики.

крім політики великих держ в, поширення смуг геополітичної вз ємодії і конфронт ції н н йближчу перспективу з леж тимуть від зд тності 6 г тьох інших кр їн ( ілорусі, кр їни, олдови, з хст ну, уби, джикист ну, уркменіст ну, иргизст ну, збекист ну, йв ню, кист ну т деяких інших), які опинилися всередині ктивних впливів різних центрів, подол ти зовнішні т внутрішні виклики й зробити вив жений геополітичний вибір.

1. ністрянський . . еополітичний тиск осії т укр їнські перспективи / . . н ністрянський // ніверсум. - 2010. - № 11-12.

2. удряченко . . еополітик / . . удряченко, . . удич, . . p мов. - ., 2004.

3. олітичн геогр фія т геополітик // . . ценко, . . т фійчук, . . р йчевський т ін. - ., 2007.

4. т тистичний щорічник кр їни з 2007 рік. - ., 2008.

5. рохимчук . . олітичн геогр фія світу / . . рохимчук, . . едунь. ., 2007. 


\title{
FOREIGN GEOPOLITICS OF GREAT POWERS: COMPARATIVE ANALYSIS OF INTERESTS, VECTORS AND CONCRETE RESULTS
}

\author{
Myroslav Dnistryanskyy \\ Ivan Franko National University of Lviv, \\ P. Doroshenko Str., 41, UA - 79000 Lviv, Ukraine
}

Comparative analysis of objectives and basic directions of geopolitics of the United States, Great Britain, Germany, France, Russia and China are made. A place of Ukraine in geopolitics of great powers is appointed. Contradictions of realization of geopolitical interests by great powers in context of global security and sustainable development are shown.

Key words: geopolitics, geopolitical analysis, great powers, foreign policy, geopolitical interests.

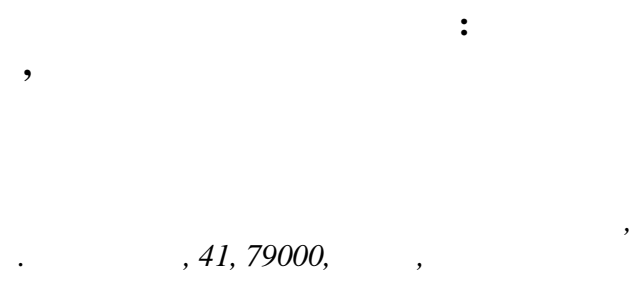

дел но ср внительный н лиз целей и основных н пр влений геополитики , еликобрит нии, ерм нии, р нции, оссии и ит я. бозн чено место кр ины в геополитике великих держ в. скрыто противоречия ре лиз ции великими держ в ми своих геополитических интересов в контексте мировой безоп сности и устойчивого р звития.

лючевые слов : геополитик, геополитический н лиз, великие держ вы, внешняя политик , геополитические интересы. 